ORIGINAL ARTICLE

\section{Entecavir versus Lamivudine for Patients with HBeAg-Negative Chronic Hepatitis B}

\author{
Ching-Lung Lai, M.D., Daniel Shouval, M.D., Anna S. Lok, M.D., \\ Ting-Tsung Chang, M.D., Hugo Cheinquer, M.D., Zachary Goodman, M.D., Ph.D., \\ Deborah DeHertogh, M.D., Richard Wilber, M.D., Richard C. Zink, Ph.D., \\ Anne Cross, Ph.D., Richard Colonno, Ph.D., and Lori Fernandes, M.D., \\ for the BEHoLD Al463027 Study Group*
}

\section{ABSTRACT}

\section{BACKGROUND}

Entecavir is a potent and selective antiviral agent that has demonstrated efficacy in phase 2 studies in patients with hepatitis B e antigen (HBeAg)-negative chronic hepatitis B.

METHODS

In this phase 3, double-blind trial, we randomly assigned 648 patients with HBeAgnegative chronic hepatitis $B$ who had not previously been treated with a nucleoside analogue to receive $0.5 \mathrm{mg}$ of entecavir or $100 \mathrm{mg}$ of lamivudine once daily for a minimum of 52 weeks. The primary efficacy end point was histologic improvement (a decrease by at least two points in the Knodell necroinflammatory score, without worsening of fibrosis).

\section{RESULTS}

Histologic improvement after 48 weeks of treatment occurred in 208 of 296 patients in the entecavir group who had adequate baseline liver-biopsy specimens that could be evaluated (70 percent), as compared with 174 of 287 such patients in the lamivudine group (61 percent, $\mathrm{P}=0.01$ ). More patients in the entecavir group than in the lamivudine group had undetectable serum hepatitis B virus (HBV) DNA levels according to a polymerase-chain-reaction assay ( 90 percent vs. 72 percent, $\mathrm{P}<0.001$ ) and normalization of alanine aminotransferase levels (78 percent vs. 71 percent, $\mathrm{P}=0.045$ ). The mean reduction in serum HBV DNA levels from baseline to week 48 was greater with entecavir than with lamivudine (5.0 vs. $4.5 \log$ [on a base-10 scale] copies per milliliter, $\mathrm{P}<0.001$ ). There was no evidence of resistance to entecavir. Safety and adverse-event profiles were similar in the two groups.

\section{CONCLUSIONS}

Among patients with HBeAg-negative chronic hepatitis B who had not previously been treated with a nucleoside analogue, the rates of histologic improvement, virologic response, and normalization of alanine aminotransferase levels were significantly higher at 48 weeks with entecavir than with lamivudine. The safety profile of the two agents was similar, and there was no evidence of viral resistance to entecavir. (ClinicalTrials.gov number, NCT00035789.)
From the Queen Mary Hospital, Hong Kong, China (C.-L.L.); Hadassah-Hebrew University Hospital, Jerusalem, Israel (D.S.); University of Michigan, Ann Arbor (A.S.L.); National Cheng Kung University Medical College, Tainan, Taiwan (T.-T.C.); Universidade Federal do Rio Grande do Sul, Porto Alegre, Brazil (H.C.); Armed Forces Institute of Pathology, Washington, D.C. (Z.G.); University of Connecticut, Farmington (D.D.); and Bristol-Myers Squibb Pharmaceutical Research Institute, Wallingford, Conn. (R.W., R.C.Z., A.C., R.C., L.F.). Address reprint requests to Dr. Lai at the University Department of Medicine, Queen Mary Hospital, Hong Kong, China, or at hrmelcl@hkucc.hku.hk.

* Other members of the Benefits of Entecavir for Hepatitis B Liver Disease (BEHoLD) Al463027 Study Group are listed in the Appendix.

N EnglJ Med 2006;354:1011-20. Copyright @ 2006 Massachusetts Medical Society. 
$\mathrm{H}$ EPATITIS B VIRUS (HBV) INFECTION IS A serious global health concern. Approximately 350 million people worldwide are chronically infected, and 500,000 to 1.2 million deaths per year are attributed to $\mathrm{HBV}$-associated complications. $^{1,2}$ A common variant of HBV infection occurs in patients who test negative for hepatitis B e antigen (HBeAg) and positive for antibodies against $\mathrm{HBeAg}$ (anti-HBe) and in whom serum HBV DNA and alanine aminotransferase levels remain persistently or intermittently elevated. ${ }^{3-5}$ The median worldwide prevalence of HBeAgnegative disease in hepatitis $B$ surface antigen (HBsAg)-positive carriers was reported to be 33 percent in 2002 and is increasing. ${ }^{5}$

HBeAg-negative HBV develops spontaneously through mutations in the precore or core promoter regions of the viral genome such that $\mathrm{HBeAg}$ is no longer expressed or is down-regulated, and it has been suggested that this gives the mutant an immunologic advantage over wild-type HBV., However, HBeAg-negative chronic hepatitis B is a heterogeneous condition, and wild-type HBV may also be responsible for disease activity in some patients. ${ }^{6,7}$ The clinical profile of HBeAgnegative chronic hepatitis $B$ differs from that of HBeAg-positive disease in that patients are typically older, ${ }^{4}$ serum HBV DNA levels are usually lower, ${ }^{8,9}$ and liver disease tends to fluctuate. ${ }^{10-12}$ Patients with HBeAg-negative chronic hepatitis B have more advanced liver disease, and the likelihood of spontaneous remission is very low. ${ }^{4,11}$

The end point of treatment for HBeAg-negative chronic hepatitis B is unknown. HBeAg loss or seroconversion cannot be used to assess response, and treatment usually focuses on suppression of HBV DNA and normalization of alanine aminotransferase levels. ${ }^{13}$ Effective suppression of HBV DNA without development of resistance among HBeAg-negative patients has been associated with improved histologic findings in the liver and longterm clinical benefit. ${ }^{14-16}$ Treatment guidelines support the use of interferon, lamivudine, or adefovir for HBeAg-negative chronic hepatitis B in patients with viremia and elevated alanine aminotransferase levels. ${ }^{17-20}$

Entecavir (Baraclude, Bristol-Myers Squibb) is a potent and highly selective inhibitor of $\mathrm{HBV}$ DNA polymerase. ${ }^{21}$ In a double-blind, randomized phase 3 study of HBeAg-positive patients who had not previously received a nucleoside analogue, entecavir resulted in significantly higher rates of histologic, virologic, and biochemical improvement than did lamivudine, with a similar safety profile. $^{22}$ The current study was designed to compare the efficacy and safety of entecavir with that of lamivudine (Epivir-HBV, GlaxoSmithKline) after 48 weeks of treatment in patients with HBeAg-negative chronic hepatitis B who had not previously received a nucleoside analogue.

METHODS

\section{STUDY DESIGN}

The design of this randomized, double-blind, controlled study was nearly identical to that of the study of HBeAg-positive patients reported by Chang et al. elsewhere in this issue of the Journal. ${ }^{22} \mathrm{~Pa}-$ tients were recruited from 146 centers worldwide, including Europe and the Middle East (68 centers), Asia (25), Australia (11), North America (30), and South America (12), and received $0.5 \mathrm{mg}$ of entecavir or $100 \mathrm{mg}$ of lamivudine once a day for a minimum of 52 weeks. Clinical management decisions were made at week 52, on the basis of the results of branched-chain DNA assays (Quantiplex, Chiron) and alanine aminotransferase assays on serum samples obtained at week 48 .

Patients who had a response (defined by an HBV DNA level below 0.7 megaequivalents [MEq] per milliliter according to branched-chain DNA assay and an alanine aminotransferase level below 1.25 times the upper limit of the normal range) or a nonresponse (defined by an HBV DNA level of $0.7 \mathrm{MEq}$ per milliliter or greater) were to discontinue study treatment.

Patients who had a response at week 48 and discontinued treatment were followed for 24 weeks after the cessation of treatment. In this way, we investigated whether the virologic and biochemical benefits of antiviral therapy were sustained after the discontinuation of treatment. Patients who had only a virologic response (defined by an HBV DNA level below 0.7 MEq per milliliter and an alanine aminotransferase level of at least 1.25 times the upper limit of normal) were offered continued therapy for up to 96 weeks.

The study was conducted in accordance with the ethics principles of the Declaration of Helsinki and was consistent with Good Clinical Practice guidelines and applicable local regulatory requirements. Written informed consent was obtained from all randomly assigned patients.

The study was designed by the sponsor (Bristol- 
Myers Squibb) in collaboration with expert hepatologists who comprised the Benefits of Entecavir for Hepatitis B Liver Disease (BEHoLD) Study Group. The sponsor collected the data, monitored the conduct of the study, performed the statistical analyses, and coordinated the writing of the manuscript with all authors. Data were unblinded for statistical analysis after the database was locked. The authors had access to the complete study reports, were actively involved in data analysis and interpretation, and approved the final manuscript. The academic authors vouch for the veracity and completeness of the data and the data analyses.

\section{STUDY POPULATION}

Eligible patients were 16 years of age or older and had HBeAg-negative chronic hepatitis B and compensated liver function (a total serum bilirubin level of $2.5 \mathrm{mg}$ per deciliter [42.8 $\mu \mathrm{mol}$ per liter] or less, a prothrombin time not more than three seconds longer than normal or an international normalized ratio not greater than 1.5, a serum albumin level of at least $3.0 \mathrm{~g}$ per deciliter, and no history of variceal bleeding or hepatic encephalopathy). Eligible patients also had detectable HBsAg for at least 24 weeks before screening, evidence of chronic hepatitis on a baseline liverbiopsy specimen obtained within 52 weeks before randomization, evidence of HBV DNA by any commercial assay at least 2 weeks before screening, undetectable $\mathrm{HBeAg}$, detectable anti-HBe, a serum HBV DNA level of at least 0.7 MEq per milliliter according to the branched-chain DNA assay at screening, and a serum alanine aminotransferase level 1.3 to 10.0 times the upper limit of normal at screening.

Exclusion criteria included coinfection with hepatitis $\mathrm{C}$, hepatitis $\mathrm{D}$, or the human immunodeficiency virus; the presence of other forms of liver disease; use of interferon alfa, thymosin $\alpha$, or antiviral agents with activity against hepatitis B within 24 weeks before randomization; previous lamivudine therapy lasting more than 12 weeks; an alpha fetoprotein level greater than 100 ng per milliliter; a history of ascites requiring diuretics or paracentesis; and previous treatment with entecavir.

\section{EFFICACY END POINTS}

The primary and secondary efficacy end points were the same as those in the study of HBeAg- positive patients, ${ }^{22}$ except that HBeAg loss and seroconversion were not secondary end points in the present study. The primary efficacy end point was the proportion of patients with histologic improvement, defined as improvement by at least two points in the Knodell necroinflammatory score, with no worsening in the Knodell fibrosis score at week 48 , relative to baseline. ${ }^{23}$

Secondary efficacy end points at week 48 included the reduction in the HBV DNA level from baseline and the proportion of patients with undetectable HBV DNA, as measured by the Roche COBAS Amplicor polymerase-chain-reaction (PCR) assay (version 2.0; lower limit of quantification, 300 copies per milliliter); the decrease in the Ishak fibrosis score; and normalization of serum alanine aminotransferase (less than 1.0 times the upper limit of normal).

\section{SAFETY ANALYSIS}

The safety analysis included data from all 638 treated patients during treatment, including the second year of treatment for patients who continued for more than 52 weeks. The primary safety end point was the proportion of patients who discontinued the study medication because of clinical or laboratory-determined adverse events. Other safety evaluations included analyses of adverse events, serious adverse events, and deaths. Flares of hepatitis during treatment were defined as elevations in the alanine aminotransferase level to more than twice the baseline level and to more than 10 times the upper limit of normal. Posttreatment flares were defined as elevations in alanine aminotransferase to more than twice the reference level and to more than 10 times the upper limit of normal, where the reference level was the lesser of the baseline value and the end-oftreatment value.

\section{RESISTANCE ANALYSIS}

Two sampling schemes were used to identify emerging HBV polymerase substitutions that may be associated with reduced susceptibility to entecavir. Paired samples from 211 randomly selected patients in the entecavir group were genotypically analyzed. HBV DNA was extracted and amplified with the use of PCR, and amino acids 1 through 344 of the reverse transcriptase were sequenced as described elsewhere. ${ }^{24}$ Substitutions that emerged during therapy were inserted into recombinant clones and analyzed in cell-culture phenotypic 
assays for susceptibility to entecavir. ${ }^{24}$ The second sampling scheme involved genotypic and phenotypic analyses of all paired samples from all patients meeting the criterion for virologic rebound (defined as a confirmed increase in the HBV DNA level by at least $1 \log$ [on a base-10 scale] copy per milliliter from the nadir value, according to PCR assay, while the patient was receiving the study medication).

\section{STATISTICAL ANALYSIS}

A two-stage evaluation was planned. First, noninferiority to lamivudine was tested, and if noninferiority was established, a second test for superiority was conducted. The planned sample size, 315 per group, had 90 percent power to demonstrate noninferiority with respect to the primary efficacy end point, assuming response rates of 60 percent for lamivudine and 64 percent for entecavir, a 25 percent rate of missing biopsy specimens obtained at week 48 , and a -10 percent boundary for the 95 percent lower confidence limit for the difference in proportions. The study had a single primary end point (histologic improvement).

Patients with missing or inadequate biopsy specimens obtained at week 48 were considered not to have had a histologic response. In proportion analyses of HBV DNA levels and alanine aminotransferase levels, treated patients with a missing value for an end point were considered not to have had a response for that end point. To compare the means of continuous variables, we used t-tests based on linear regression models, adjusted for baseline measurements. There were no interim analyses of efficacy. All reported $\mathrm{P}$ values are two-sided and were not adjusted for multiple testing.

\section{RESULTS}

\section{STUDY POPULATION}

Of 1468 patients who were enrolled and screened, 648 were randomly assigned to treatment (331 to the entecavir group and 317 to the lamivudine group), and 638 (325 in the entecavir group and 313 in the lamivudine group) received, in a blinded fashion, at least one dose of study drug. Of these 638 patients, 583 had adequate baseline liver-biopsy specimens with a Knodell necroinflammatory score of 2 or greater; 31 of 296 patients receiving entecavir (10 percent) and 37 of 287 patients receiving lamivudine (13 percent) who had baseline liver-biopsy specimens had missing specimens at week 48. The two treatment groups were well balanced at baseline (Table 1). Of the 820 patients not randomly assigned to treatment, 774 did not meet one or more of the inclusion criteria.

Three hundred eleven patients assigned to receive entecavir (96 percent) and 296 patients assigned to receive lamivudine (95 percent) completed 52 weeks of treatment. No patient discontinued treatment because of treatment failure or lack of efficacy during the 52-week, blinded treatment period.

\section{HISTOLOGIC AND BIOCHEMICAL RESPONSE}

After criteria for noninferiority were met, we conducted tests for superiority. Histologic improvement occurred in significantly more patients in the entecavir group than in the lamivudine group at week 48 (70 percent vs. 61 percent, $\mathrm{P}=0.01$ ) (Table 2). There was no histologic improvement in 26 percent of patients in the lamivudine group and 19 percent of patients in the entecavir group. Treatment with entecavir or lamivudine resulted in improved Ishak fibrosis scores in 36 percent and 38 percent of the patients, respectively $(\mathrm{P}=0.65)$. The alanine aminotransferase level was normalized in significantly more patients treated with entecavir than those treated with lamivudine at week 48 (78 percent vs. 71 percent, $\mathrm{P}=0.045$ ) (Table 3).

\section{VIROLOGIC AND SEROLOGIC RESPONSE}

The mean reduction from baseline in serum HBV DNA levels according to PCR assay at week 48 was significantly greater in the entecavir group than in the lamivudine group (5.0 log copies vs. $4.5 \log$ copies per milliliter, $\mathrm{P}<0.001$ ) (Table 3 and Fig. 1B). HBV DNA levels in the entecavir group fell continuously during treatment, and 90 percent of the patients had undetectable levels at week 48 according to PCR assay. In contrast, HBV DNA levels in the lamivudine group remained distributed over a wide range of values, and 72 percent of the patients had undetectable levels at week 48 according to PCR assay $(\mathrm{P}<0.001)$ (Table 3 and Fig. 1A). HBsAg loss had occurred in one patient in each treatment group at week 48.

\section{RESPONSES AT WEEK 48 AND AFTER TREATMENT}

At week 48, 275 patients in the entecavir group (85 percent) and 245 patients in the lamivudine group (78 percent) had a response $(\mathrm{P}=0.04)$, as 


\begin{tabular}{|c|c|c|c|}
\hline Characteristic & Entecavir $(\mathrm{N}=325)$ & Lamivudine ( $\mathrm{N}=313$ ) & $P$ Value \\
\hline Age $-y r$ & $44 \pm 11$ & $44 \pm 11$ & 1.00 \\
\hline Male sex - no. (\%) & $248(76)$ & $236(75)$ & 0.85 \\
\hline \multicolumn{4}{|l|}{ Race or ethnic group — no. $(\%) \dagger$} \\
\hline White & $193(59)$ & $176(56)$ & 0.74 \\
\hline Asian & $122(38)$ & $129(41)$ & \\
\hline Black & $8(2)$ & $7(2)$ & \\
\hline Other & $2(<1)$ & $1(<1)$ & \\
\hline \multicolumn{4}{|l|}{ Region - no. (\%) } \\
\hline Europe and the Middle East & $156(48)$ & $148(47)$ & 1.00 \\
\hline Asia and Australia & $106(33)$ & $104(33)$ & \\
\hline South America & $35(11)$ & $34(11)$ & \\
\hline North America & $28(9)$ & $27(9)$ & \\
\hline Knodell necroinflammatory scoreł & $8.0 \pm 2.7$ & $7.7 \pm 2.8$ & 0.18 \\
\hline Ishak fibrosis score & $2.4 \pm 1.2$ & $2.5 \pm 1.3$ & 0.31 \\
\hline$\geq 3$ (bridging fibrosis) —\% & 43 & 41 & 0.68 \\
\hline$\geq 5$ (cirrhosis) - \% & 5 & 10 & 0.06 \\
\hline \multicolumn{4}{|l|}{ Mean HBV DNA level } \\
\hline By branched-chain DNA assay - MEq/ml & $1.2 \pm 1.0$ & $1.2 \pm 1.0$ & 1.00 \\
\hline By PCR assay — log copies/ml & $7.6 \pm 1.8$ & $7.6 \pm 1.7$ & 1.00 \\
\hline HBeAg-negative - no. (\%) & $322(99)$ & $309(99)$ & 0.72 \\
\hline Anti-HBe-positive — no. (\%) & 323 (99) & $312(100)$ & 1.00 \\
\hline \multicolumn{4}{|l|}{ Viral genotype - no. (\%) } \\
\hline A & $33(10)$ & $33(11)$ & 0.45 \\
\hline B & $46(14)$ & $60(19)$ & \\
\hline C & $57(18)$ & $51(16)$ & \\
\hline $\mathrm{D}$ & $157(48)$ & $135(43)$ & \\
\hline Other, indeterminate, or missing & $32(10)$ & $34(11)$ & \\
\hline Alanine aminotransferase - IU/liter & $141 \pm 114.7$ & $143 \pm 119.4$ & 0.83 \\
\hline Prior anti-HBV therapy — no. (\%) & $49(15)$ & $45(14)$ & \\
\hline Interferon & $42(13)$ & $39(12)$ & 0.91 \\
\hline Lamivudine & $9(3)$ & $12(4)$ & 0.51 \\
\hline
\end{tabular}

* Plus-minus values are means \pm SD. Percentages may not sum to 100 because of rounding. The Knodell inflammatory score can range from 0 to 18, with higher scores indicating more severe chronic hepatitis. The Ishak fibrosis score is based on a scale of 0 to 6 , where 0 indicates no fibrosis and 5 or higher indicates cirrhosis. HBV denotes hepatitis B virus, PCR polymerase chain reaction, and $\mathrm{HBeAg}$ hepatitis B e antigen.

$\dagger$ Race or ethnic group was determined by the investigator.

Adequate baseline biopsy specimens were available for 303 patients in the entecavir group and 293 patients in the lamivudine group.

defined by the protocol (HBV DNA level, $<0.7 \mathrm{MEq} \quad$ sponse (HBV DNA level, $<0.7 \mathrm{MEq}$ per milliliter; per milliliter, according to branched-chain DNA alanine aminotransferase level, $\geq 1.25$ times the assay; alanine aminotransferase level, $<1.25$ times upper limit of normal). Three patients in the enthe upper limit of normal). Thirty-four patients tecavir group ( $<1$ percent) and 18 in the lamivuin the entecavir group (10 percent) and 34 in the dine group (6 percent) had a nonresponse (HBV lamivudine group (11 percent) had a virologic re- DNA level, $\geq 0.7 \mathrm{MEq}$ per milliliter). 


\begin{tabular}{|c|c|c|c|c|}
\hline End Point & $\begin{array}{l}\text { Entecavir } \\
(\mathrm{N}=325)\end{array}$ & $\begin{array}{l}\text { Lamivudine } \\
(\mathrm{N}=313)\end{array}$ & $\begin{array}{l}\text { Difference Estimate } \\
\qquad(95 \% \mathrm{Cl})^{*}\end{array}$ & $P$ Value \\
\hline $\begin{array}{c}\text { Adequate baseline biopsy specimen and Knodell } \\
\text { necroinflammatory score } \geq 2-\text { no. }\end{array}$ & 296 & 287 & & \\
\hline Improvement — no. (\%) $\dagger$ & $208(70)$ & $174(61)$ & $9.6(2.0-17.3)$ & 0.01 \\
\hline No improvement - no. (\%) & $57(19)$ & $76(26)$ & & \\
\hline \multicolumn{5}{|l|}{ Mean Knodell necroinflammatory scoret } \\
\hline Baseline & 8.1 & 7.8 & & \\
\hline Week 48 & 4.2 & 4.6 & & \\
\hline
\end{tabular}

* The difference estimate was calculated for the entecavir group as compared with the lamivudine group. $\mathrm{Cl}$ denotes confidence interval.

$\uparrow$ Histologic improvement was defined as a decrease by at least 2 points in the Knodell necroinflammatory score, with no worsening in the fibrosis component of the score.

tThere were 265 treated patients in the entecavir group and 250 in the lamivudine group with evaluable pairs of biopsy specimens.

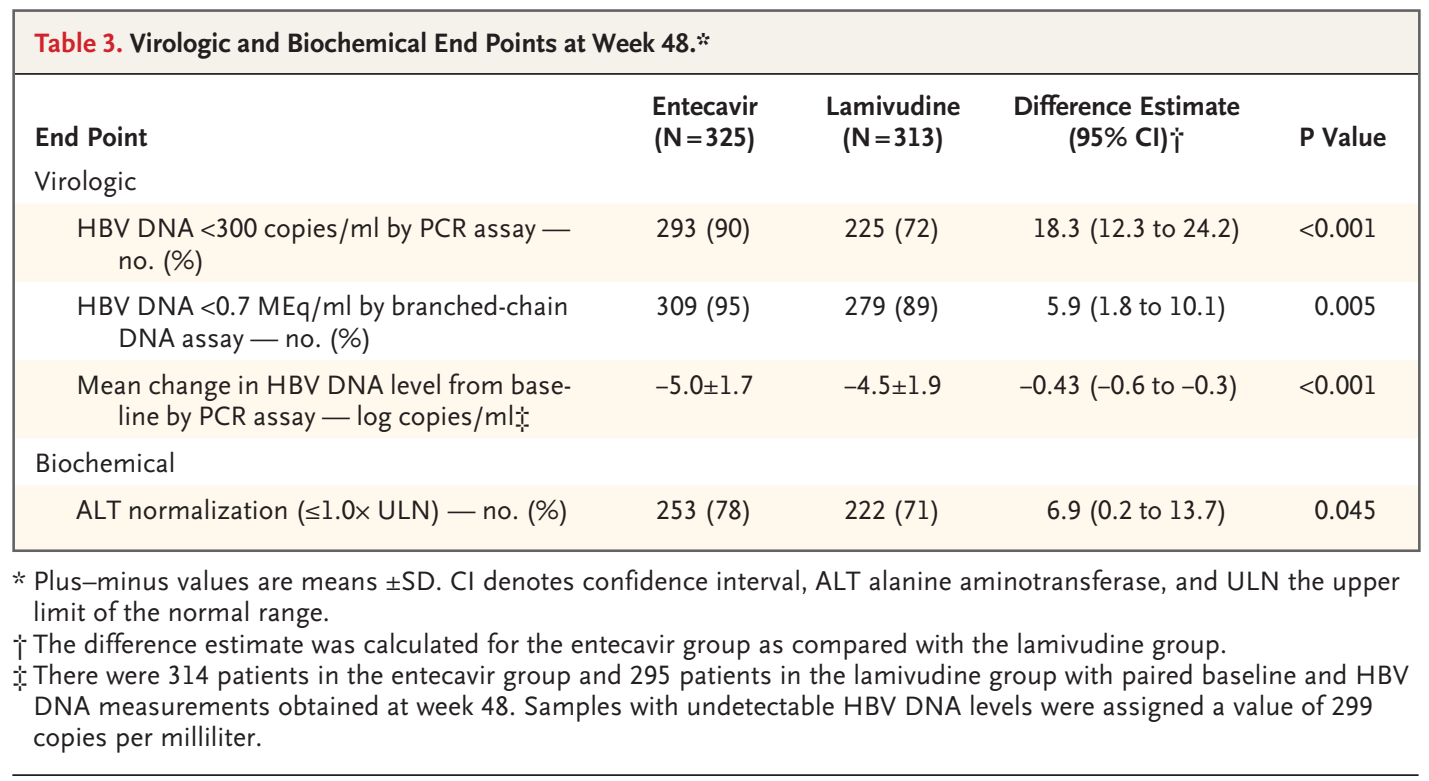

Among the patients who had a protocoldefined response at week 48 and who discontinued study treatment, 124 of 259 patients in the entecavir group (48 percent) and 78 of 220 patients in the lamivudine group ( 35 percent) had a sustained response for at least 24 weeks after the discontinuation of treatment.

\section{RESISTANCE}

There was no evidence of resistance to entecavir at week 48 in paired samples from 211 randomly selected patients in the entecavir group. Furthermore, 5 patients receiving entecavir (2 percent) and 25 patients receiving lamivudine ( 8 percent) had virologic rebound. Genotypic analysis at week 48 of isolates from the five patients treated with entecavir revealed no emerging substitutions when comparing baseline and samples obtained at week 48 , and samples obtained at week 48 retained full phenotypic susceptibility to entecavir. Genotypic analysis of isolates obtained at week 48 from the 25 patients in the lamivudine group who had virologic rebound revealed that 20 (80 percent) had mutations in the YMDD (tyrosine, methionine, aspartate, aspartate) motif of the HBV polymerase gene.

\section{SAFETY AND ADVERSE EVENTS}

The mean exposure to study therapy was 56 weeks for the entecavir group and 56 weeks for the la- 


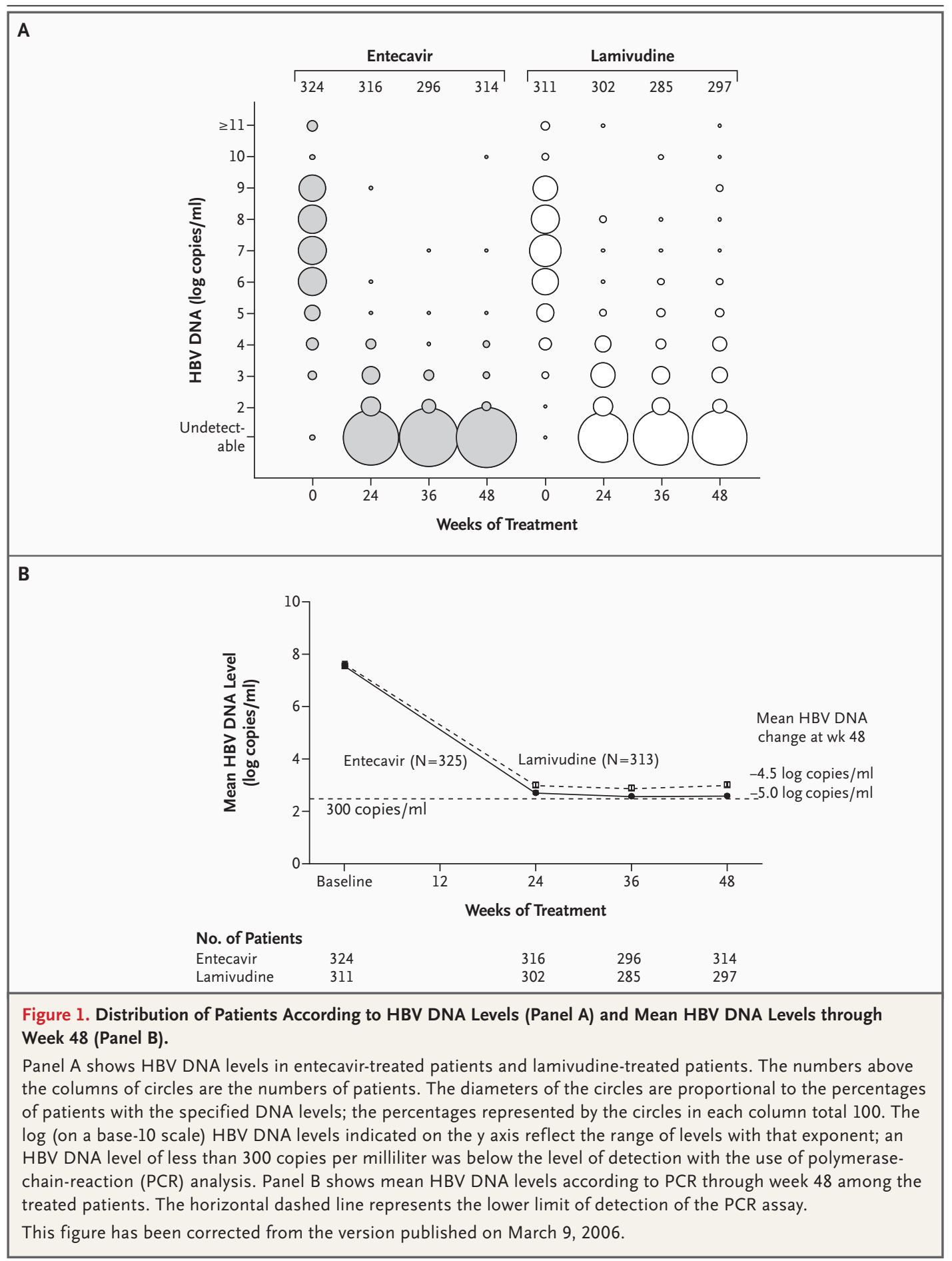

mivudine group. The frequency of adverse events gia, diarrhea, insomnia, cough, nausea, and myduring treatment was similar between the two algia, most of which were of mild-to-moderate treatment groups (Table 4). The most frequent ad- severity. The frequencies of serious adverse events verse events were headache, upper respiratory tract were also similar in the two treatment groups. infection, upper abdominal pain, influenza, naso- There were fewer discontinuations due to adverse pharyngitis, dyspepsia, fatigue, back pain, arthral- events in the entecavir group (six) than in the la- 


\begin{tabular}{|c|c|c|c|}
\hline \multirow[t]{2}{*}{ Timing and Event } & Entecavir ( $\mathrm{N}=325)$ & Lamivudine $(\mathrm{N}=313)$ & P Value \\
\hline & \multicolumn{2}{|c|}{ no. of patients (\%) } & \\
\hline \multicolumn{4}{|l|}{ During treatment } \\
\hline Any adverse event & $246(76)$ & $248(79)$ & 0.30 \\
\hline Serious adverse event & $21(6)$ & $24(8)$ & 0.64 \\
\hline Discontinuation due to adverse event & $6(2)$ & $9(3)$ & 0.44 \\
\hline ALT $>2 \times$ baseline and $>10 \times \mathrm{ULN}^{\dagger}$ & $3(<1)$ & $5(2)$ & 0.50 \\
\hline ALT $>2 \times$ baseline and $>5 \times$ ULN & $6(2)$ & $10(3)$ & 0.32 \\
\hline Death & $2(<1)$ & 0 & 0.50 \\
\hline \multicolumn{4}{|l|}{ Post-treatment follow-up』 } \\
\hline ALT $>2 \times$ reference value and $>10 \times$ ULN 9 & $23(8)$ & $29(11)$ & 0.19 \\
\hline ALT $>2 \times$ reference value and $>5 \times$ ULN $\$$ & $36(12)$ & $77(29)$ & $<0.001$ \\
\hline
\end{tabular}

* ALT denotes alanine aminotransferase, and ULN upper limit of normal.

$\dagger$ According to the protocol, these findings constituted alanine aminotransferase flares during treatment.

The analysis was conducted post hoc.

$\int$ There were 297 patients in the entecavir group and 263 in the lamivudine group who had entered post-treatment as of the data cut-off.

IAccording to the protocol, these findings constituted post-treatment alanine aminotransferase flares. The reference level was the lesser of the baseline value and the end-of-treatment alanine aminotransferase values.

mivudine group (nine), and no patient discontinued study therapy because of an alanine aminotransferase flare.

Elevations in alanine aminotransferase levels rarely occurred during treatment and were observed with similar frequencies in the two treatment groups (Table 4). Alanine aminotransferase flares during treatment were observed in three patients in the entecavir group and five patients in the lamivudine group. In the entecavir group, two of the alanine aminotransferase flares occurred early in therapy and were associated with a reduction in HBV DNA by at least 2 log copies per milliliter, according to branched-chain DNA assay. The other flare occurred one day after the last dose of entecavir and resolved spontaneously within two months. None of the entecavir-treated patients had hepatic decompensation.

In the lamivudine group, two of the five alanine aminotransferase flares were associated with a reduction in HBV DNA by at least 2 log copies per milliliter. The other three flares were associated with increasing HBV DNA levels, and one was associated with the development of ascites.

Of the 297 patients in the entecavir group and 263 patients in the lamivudine group who entered post-treatment follow-up by the data cut-off, alanine aminotransferase level flares occurred in 23 (8 percent) and 29 (11 percent), respectively, during follow-up.
Two deaths, considered unrelated to study therapy, occurred during the treatment period, both in the entecavir group (Table 4). One patient, who had a history of cirrhosis, died at week 45 , after hepatocellular carcinoma was diagnosed at week 42 of entecavir therapy. Pneumonia developed in the other patient, who had a history of diabetes mellitus and cirrhosis and subsequently died at week 8 from multiorgan failure.

\section{DISCUSSION}

Suppression of viral replication is a principal goal of therapy in patients with HBeAg-negative chronic hepatitis B. A retrospective analysis of long-term lamivudine therapy in HBeAg-negative patients showed that those with well-compensated cirrhosis who maintained HBV DNA suppression had reduced rates of hepatocellular carcinoma and progression of liver disease. ${ }^{16}$ These results are supported by Liaw et al., who showed that for patients with HBeAg-negative or HBeAg-positive chronic hepatitis B who had cirrhosis or advanced fibrosis, treatment with lamivudine slows the progression of liver disease, presumably by suppressing viral replication and decreasing the resultant necroinflammatory response. ${ }^{25}$

In this trial, entecavir was associated with significantly greater suppression of viral replication than was lamivudine, as measured by both the 
proportion of patients who had undetectable levels of HBV DNA 48 weeks after the start of treatment and the magnitude of reduction in the level of HBV DNA from baseline. Significantly more patients had normalization of alanine aminotransferase levels and histologic improvement after treatment with entecavir than after treatment with lamivudine. Although this suggests that entecavir may be more effective than lamivudine in preventing adverse clinical outcomes among patients with HBeAg-negative chronic hepatitis B, longer surveillance is necessary.

The potent suppression of viral replication associated with treatment with entecavir decreases the risk of development of resistant virus. In this study, there was no evidence of the emergence of resistance in any entecavir-treated patients. $\mathrm{Al}$ though several emerging resistance substitutions occurred, none were present in more than three patients and, most important, none resulted in reduced susceptibility to entecavir when tested in phenotypic assays. Monitoring of entecavir treatment to determine long-term resistance rates is ongoing.

Lamivudine has been used extensively for patients with HBeAg-negative chronic hepatitis B, with few adverse effects. The similar safety profiles of entecavir and lamivudine in this study demonstrate that entecavir has few adverse reactions; surveillance of the safety of long-term entecavir treatment continues.

Optimal treatments for patients with HBeAgnegative chronic hepatitis $B$ continue to evolve. For most patients, long-term treatment is necessary to maintain viral suppression and remission of liver disease. Pegylated interferon alfa demonstrated efficacy but has an adverse-event profile similar to that of interferon alfa. ${ }^{26-29}$ One year of treatment with lamivudine produced histologic improvement in 60 percent of patients, with re- sistance rates of up to 27 percent. ${ }^{30,31}$ Treatment with adefovir for one year resulted in histologic improvement in 64 percent and normalization of the alanine aminotransferase level in 72 percent of patients, with no evidence of resistance. ${ }^{32}$ After four years of treatment with adefovir, resistance developed in up to 18 percent of patients. ${ }^{33}$

The present study of entecavir and lamivudine in patients with HBeAg-negative chronic hepatitis B complements a similar trial in patients with HBeAg-positive chronic hepatitis B. ${ }^{22}$ Entecavir offers the potential to control HBV replication, improve histology, and arrest or reverse the progression of liver disease consistently and predictably. Together with its safety profile, this suggests that entecavir should be considered as a primary therapy for HBeAg-negative chronic hepatitis B in patients not previously treated with a nucleoside analogue.

Supported by Bristol-Myers Squibb.

Presented in part at the 55th annual meeting of the American Association for the Study of Liver Diseases, November 1, 2004, and the 14th biennial meeting of the Asian Pacific Association for the Study of the Liver, December 14, 2004.

Drs. Lok and Shouval report having received consulting fees from GlaxoSmithKline and grant support from Roche. Dr. Lok reports having received consulting fees from Roche, Innogenetics, XTL, Idun, Idenix, Nabi, PowderMed, and Anadys; grant support from the National Institutes of Health, Gilead, GlaxoSmithKline, Schering-Plough, and Valeant; and lecture fees from Roche. Dr. Goodman reports having received consulting fees from ScheringPlough and grant support from SciClone Pharmaceuticals and New England Research Institutes; Drs. Goodman and Lok, consulting fees from Gilead and grant support from Idenix; Dr. Shouval, lecture fees from GlaxoSmithKline and Sanofi Pasteur MSD and grant support and consulting fees from Berna Biotech; Drs. Chang and Lai, lecture fees from Bristol-Myers Squibb; Drs. Cheinquer, Lok, and Shouval, consulting fees from Bristol-Myers Squibb; and Drs. Goodman, Lai, and Lok, grant support from Bristol-Myers Squibb. Dr. DeHertogh reports having equity interest in Bristol-Myers Squibb. Drs. Zink, Cross, Colonno, Fernandes, and Wilber are full-time employees of Bristol-Myers Squibb. No other potential conflict of interest relevant to this article was reported.

We are indebted to Bruce Kreter, Pharm.D. (Bristol-Myers Squibb), for his contribution to the manuscript.

\section{APPENDIX}

Bristol-Myers Squibb scientists were D. Tenney, R. Rose, and S. Levine.

In addition to the authors, the BEHoLD AI463027 Study Group included the following investigators: North America - F. Anderson, T. Boyer, R. Brown, D. Chua, D. Dieterich, L. Cisneros Garza, R. Gish, S. Gordon, S. Han, D. LaBrecque, P. Martin, G. Minuk, T.T. Nguyen, K. O’Riordan, F. Poordad, R. Rai, V. Rustgi, M. Sherman, M. Shiffman, C. Smith, M. Swain, N. Tsai, B. Tung, and G. Wu. Asia, Pacific Islands, and Australia - S.A. Abdurachman, P. Angus, Y.-C. Chao, A. Chutaputti, P. Desmond, J. George, S. Huang, E.K. Ooi, A. Lee, S.-D. Lee, Y.-F. Liaw, C.C. Lim, H.H. Lin, G.H. Lo, G. Marinos, I. Merican, C. Pramoolsinsap, S. Roberts, M. Rosmawati, J. Sasadeusz, W. Sievert, H. Singh, C.K. Tan, T. Tanwandee, S. Thongsawat, S.S. Wu, and F. Zano. South America - A. Barone, F. Carrilho, H. Coelho, M. Ferraz, R. Focaccia, A. Gadano, F. Goncales, L. Lyra, and H. Sette. Europe and Middle East - H. Aksu, Y. Baruch, M. Bassendine, Y. Batur, A. Boron-Kaczmarska, F. Calinas, G. Carosi, W. Caselmann, A. Cerny, L. Dalmi, R.A. de Man, M. Ferret, G. Gerken, G. Germanidis, B. Gocman, Z. Gonciarz, V. Gorbakov, S. Hadziyannis, W. Halota, G. Hatzis, M. Heim, Y. Horsmans, S. Hrusovsky, V. Isakov, S. Kaymakoglu, G. Kitis, H. Klinker, K. Krogsgaard, G. Kullak-Ublick, J. Kuydowicz, Y. Lurie, M. Manns, Z. Marecek, F. Mazzotta, P. Mills, F. Nevens, A. Nimer, D. Oguz, M. Oltman, G. Pastore, C. Pedersen, V. Pokrovsky, A. Porto, V. Rafalsky, M. Raptopoulou-Gigi, M. Rizzetto, J. Garcia Samaniego, H. Senturk, M. Sikora, H. Simsek, U. Spengler, G. Storozhakov, F. Suter, E. Tsianos, R. Tur-Kaspa, H. Van Vlierberghe, E. Vinogradova, C. Yurdaydin, and S. Zeuzem. 


\section{REFERENCES}

1. Hepatitis B: fact sheet WHO/204. Geneva: World Health Organization, October 2000. (Accessed February 10, 2006, at http: //www.who.int/mediacentre/factsheets/ fs204/en.)

2. Lavanchy D. Hepatitis B virus epidemiology, disease burden, treatment, and current and emerging prevention and control measures. J Viral Hepat 2004;11:97107.

3. Hadziyannis SJ. Hepatitis B e antigen negative chronic hepatitis B: from clinica recognition to pathogenesis and treatment. Viral Hepat Rev 1995;1:7-36.

4. Hadziyannis SJ, Vassilopoulos D. Hepatitis B e antigen-negative chronic hepatitis B. Hepatology 2001;34:617-24.

5. Funk ML, Rosenberg DM, Lok ASF Worldwide epidemiology of HBeAg-negative chronic hepatitis B and associated precore and core promoter variants. J Vira Hepat 2002;9:52-61.

6. Chan HLY, Leung NWY, Hussain M Wong ML, Lok ASF. Hepatitis B e antigennegative chronic hepatitis B in Hong Kong. Hepatology 2000;31:763-8.

7. Yuen MF, Sablon E, Yuan HJ, et al. Relationship between the development of precore and core promoter mutations and hepatitis B e antigen seroconversion in patients with chronic hepatitis B virus. J Infect Dis 2002;186:1335-8.

8. Chu CJ, Hussain M, Lok ASF. Quantitative serum HBV DNA levels during different stages of chronic hepatitis B infection. Hepatology 2002;36:1408-15.

9. Manesis EK, Papatheodoridis GV, Sevastianos V, Cholongitas E, Papaioannou C, Hadziyannis SJ. Significance of hepatitis B viremia levels determined by a quan titative polymerase chain reaction assay in patients with hepatitis B e antigennegative chronic hepatitis $B$ virus infection. Am J Gastroenterol 2003;98:2261-7. 10. Papatheodoridis GV, Hadziyannis SJ. Current management of chronic hepatitis B. Aliment Pharmacol Ther 2004;19:25-37. 11. Brunetto MR, Oliveri F, Coco B, et al Outcome of anti-HBe positive chronic hepatitis B in alpha-interferon treated and untreated patients: a long-term cohort study. J Hepatol 2002;36:263-70.
12. Fattovich G. Natural history of hepatitis B. J Hepatol 2003;39:Suppl 1:S50-S58. 13. Conjeevaram HS, Lok ASF. Management of chronic hepatitis B. J Hepatol 2003; 38:Suppl 1:S90-S103. [Erratum, J Hepato 2003;38:876.

14. Rizzetto M, Tassopoulos NC, Goldin RD, et al. Extended lamivudine treatmen in patients with HBeAg-negative chronic hepatitis B. J Hepatol 2005;42:173-9.

15. Papatheodoridis GV, Dimou E, Laras A, Papadimitropoulos V, Hadziyannis SJ. Course of virologic breakthroughs under long-term lamivudine in $\mathrm{HBeAg-negative}$ precore mutant HBV liver disease. Hepatology 2002;36:219-26.

16. Di Marco V, Marzano A, Lampertico $\mathrm{P}$, et al. Clinical outcome of HBeAg-negative chronic hepatitis B in relation to virological response to lamivudine. Hepatol ogy 2004:40:883-91.

17. Lok ASF, McMahon BJ. Chronic hepatitis B: update of recommendations. Hepatology 2004;39:857-61.

18. Keeffe EB, Dieterich DT, Han SH, et al. A treatment algorithm for the management of chronic hepatitis B infection in the United States. Clin Gastroenterol Hepatol 2004;2:87-106.

19. de Franchis R, Hadengue A, Lau G, et al. EASL International Consensus Conference on Hepatitis B. J Hepatol 2003;39: Suppl 1:S3-S25.

20. Core Working Party for Asia-Pacific Consensus on Hepatitis B and C. Consensus statements on the prevention and management of hepatitis B and hepatitis $\mathrm{C}$ in the Asia-Pacific region. J Gastroen terol Hepatol 2000;15:825-41.

21. Innaimo SF, Seifer M, Bisacchi GS, Standring DN, Zahler R, Colonno RJ. Identification of BMS-200475 as a potent and selective inhibitor of hepatitis B virus. Antimicrob Agents Chemother 1997;41:1444 8.

22. Chang T-T, Gish RG, de Man R, et al. A comparison of entecavir and lamivudine for $\mathrm{HBeAg}$-positive chronic hepatitis B. N Engl J Med 2006;354:1001-10. 23. Knodell RG, Ishak KG, Black WC, et al. Formulation and application of a numerical scoring system for assessing his- tological activity in asymptomatic chronic active hepatitis. Hepatology 1981;1:431-

24. Tenney DJ, Levine SM, Rose RE, et al. Clinical emergence of entecavir-resistant hepatitis B virus requires additional substitutions in virus already resistant to lamivudine. Antimicrob Agents Chemother 2004;48:3498-507.

25. Liaw YF, Sung JJY, Chow WC, et al. Lamivudine for patients with chronic hepatitis B and advanced liver disease. $\mathrm{N}$ Engl J Med 2004;351:1521-31.

26. Lok AS, Heathcote EJ, Hoofnagle JH. Management of hepatitis B: 2000 - summary of a workshop. Gastroenterology 2001;120:1828-53.

27. Hadziyannis SJ, Papatheodoridis GV, Vassilopoulos D. Treatment of HBeAgnegative chronic hepatitis B. Semin Liver Dis 2003;23:81-8.

28. Manesis EK, Hadziyannis SJ. Interferon $\alpha$ treatment and retreatment of hepatitis B e antigen-negative chronic hepatitis B. Gastroenterology 2001;121:101-9.

29. Marcellin P, Lau GKK, Bonino F, et al. Peginterferon alfa-2a alone, lamivudine alone, and the two in combination in patients with $\mathrm{HBeAg-negative} \mathrm{chronic} \mathrm{hepa-}$ titis B. N Engl J Med 2004;351:1206-17.

30. Tassopoulos NC, Volpes R, Pastore G, et al. Efficacy of lamivudine in patients with hepatitis B e antigen-negative/hepatitis B virus DNA-positive (precore mutant) chronic hepatitis B. Hepatology 1999;29: 889-96.

31. Rizzetto M. Efficacy of lamivudine in HBeAg-negative chronic hepatitis B. J Med Virol 2002;66:435-51.

32. Hadziyannis SJ, Tassopoulos NC Heathcote EJ, et al. Adefovir dipivoxil for the treatment of hepatitis B e antigennegative chronic hepatitis B. N Engl J Med 2003;348:800-7. [Erratum, N Engl J Med 2003;348:1192.]

33. Locarnini S, Qi X, Arterburn S, et al. Incidence and predictors of emergence of adefovir resistant HBV during four years of adefovir dipivoxil (ADV) therapy for patients with chronic hepatitis B (CHB). J Hepatol 2005;42:Suppl 2:17. abstract. Copyright (c) 2006 Massachusetts Medical Society.

PERSONAL ARCHIVES IN THE JOURNAL ONLIN

Individual subscribers can store articles and searches using a feature on the Journal's Web site (www.nejm.org) called "Personal Archive."

Each article and search result links to this feature. Users can create personal folders and move articles into them for convenient retrieval later. 


\section{CORRECTION}

\section{Entecavir versus Lamivudine for Patients with} HBeAg-Negative Chronic Hepatitis B

Entecavir versus Lamivudine for Patients with $\mathrm{HBeAg}$-Negative Chronic Hepatitis B . On page 1017, the data plots in Figure 1B are incorrectly placed. A revised figure is shown here. The figure has also been corrected on the Journal's Web site at www.nejm.org. We regret the error.

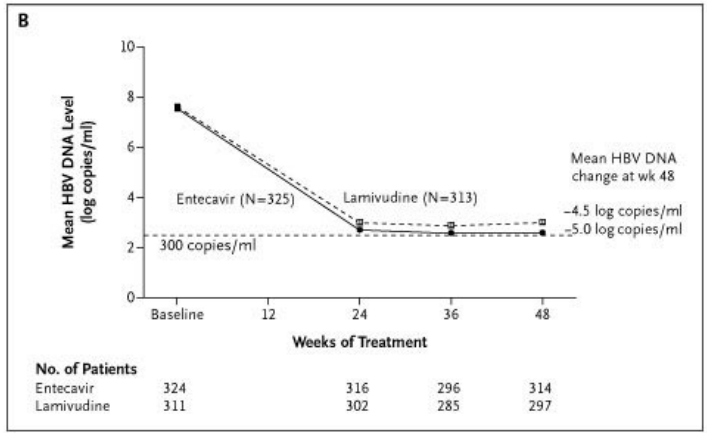

